\title{
Parasitism by Dermocystidium ranae in a population of Rana esculenta complex in Central Italy and description of Amphibiocystidium n. gen.
}

\author{
R. Pascolini ${ }^{1}$, P. Daszak ${ }^{2, *}$, A. A. Cunningham ${ }^{3}$, S. Tei $^{1}$, D. Vagnetti ${ }^{1}$, S. Bucci ${ }^{4}$, \\ A. Fagotti ${ }^{1}$, I. Di Rosa ${ }^{1}$
}

${ }^{1}$ Department of Cellular and Molecular Biology, University of Perugia, Piazza dell'Universita, 1, 06100 Perugia, Italy ${ }^{2}$ Consortium for Conservation Medicine, 61 Route 9W, Palisades, New York 10964, USA

${ }^{3}$ Institute of Zoology, Zoological Society of London, Regent's Park, London NW1 4RY, United Kingdom

${ }^{4}$ Department of Physiology and Biochemistry, University of Pisa, Lungarno Pacinotti, 43, 56124 Pisa, Italy

\begin{abstract}
We report the enigmatic parasite Dermocystidium ranae in a green frog population (Solomeo, Umbria, Italy) of the Rana esculenta complex, consisting of the parental species $R$. lessonae $(L)$ and hybrid form $R$. esculenta $(E)$. In this population a rapid $50 \%$ decline of the parental form $L$ was observed. Large dermal U-shaped cysts of $D$. ranae were found primarily on the ventral aspect of infected individuals, with a significantly higher incidence of infection in the parental species compared to the clonal hybrid. In each form, however, there was little pathological change associated with infection, and the cause of the recent declines of $R$. lessonae at this site remains unknown. In this paper we present the first ultrastructural description of an amphibian Dermocystidium sp. and we review the taxonomy of Dermocystidium, Dermosporidium and Dermomycoides spp. from amphibians. We conclude that Dermosporidium multigranulare Brož \& Kulda, 1954 is synonymous with Dermocystidium ranae Guyénot \& Naville, 1922 and, due to lack of sufficient differences between genera and significant dissimilarities with fish Dermocystidium spp., the 3 amphibian genera are synonymous. We propose that they should be designated to a new genus, Amphibiocystidium n. gen., and Dermocystidium retained for those species parasitic in fish.
\end{abstract}

KEY WORDS: Amphibian · Rana - Dermocystidium - Amphibiocystidium • Amphibian declines Resale or republication not permitted without written consent of the publisher

\section{INTRODUCTION}

In recent years, a global decline in amphibian populations has occurred (Blaustein \& Wake 1990, Houlahan et al. 2000). A number of anthropogenic factors have been causally implicated in these declines, including habitat loss, introduction of predators, chemical pollution and climate change (Halliday 2001, Kiesecker et al. 2001). Recently, a previously unknown fungal disease, chytridiomycosis (Berger et al. 1998), and ranavirus infections (Cunningham et al. 1996, Cunningham 2001) have been reported as the cause of amphibian mass mortality associated with population declines (Daszak et al. 1999). These emerging infec- tious diseases (EIDs) are part of a growing cohort of wildlife EIDs that threaten biodiversity globally (Daszak et al. 2000). The current investigation was conducted to assess the potential role of infectious disease in a recent decline of Rana lessonae at Solomeo, Umbria, Italy.

The Rana esculenta complex is a group in which clonal reproduction has arisen. $R$. esculenta $(E)$ are natural hybrids between $R$. ridibunda $(R)$ and $R$. lessonae (L) (Berger 1967, Günther 1973, Graf \& Polls Pelaz 1989). Both sexes of the hybrids reproduce hemiclonally via a hybridogenetic gametogenesis (Schultz 1969). In the germ line of these hybrids, the $L$ genome is excluded before meiosis, the remaining $R$ genome 
undergoes a premeiotic or occasionally a prediplotene meiotic endoreduplication (Tunner \& Heppich-Tunner 1991) and 2 apparently normal meiotic divisions resulting in functional, genetically identical haploid gametes that contain an unrecombined $R$ genome. Hybridity in these lineages is restored each generation through fertilization of these gametes by gametes from syntopic $L$. The vast majority of $E$ lineages coexist as sexual parasites with the host species $L$.

The $L-E$ system population is widespread throughout Europe (Uzzell \& Berger 1975). The proportion of parental species and hybrids in natural populations depends on the environment. It it hypothesized that this is because hybrids are more tolerant to environmental stress than parental species: $E$, in contrast to $L$, appears to produce metamorphs that are better adapted to hypoxic conditions and fungicides ordinarily used in agriculture (Tunner \& Nopp 1979, Semlitsch \& Reyer 1992, Fioramonti et al. 1997, Hotz et al. 1999). Because of this apparent dichotomy in susceptibility to environmental variables, the hybridogenetic system may represent an interesting model for examining the ecology of pathogens. A hybridogenetic $L-E$ system is present on the Italian peninsula; it is formed by a lessonae-like parental species and its esculenta-like hybrid (Uzzell \& Hotz 1979, Uzzell 1983, Günther \& Plötner 1994). Previous research on the composition of the hybridogenetic system conducted in the Trasimeno Lake district in Central Italy suggests that the parental species may be threatened by environmental stressors (Bucci et al. 2000). It is of interest that in a restricted area (Solomeo), close to Trasimeno Lake, a frequency reduction has been observed in the parental species with respect to the hybrid form within the time span of 1998 to 2000. In this paper we report the preliminary results of pathological and parasitological investigations on this population. The enigmatic parasite Dermocystidium ranae is reported from both the parental species and the hybrid form. The incidence was significantly higher in the parental species. The ultrastructure of mature Dermocystidium cysts is described and its taxonomy discussed. It remains unknown if this parasite is a significant pathogen of green frogs, and the cause of decline in the parent population has yet to be deduced.

\section{MATERIALS AND METHODS}

Collections of specimens. Live, metamorphosed green frogs of similar size were collected from ponds and streams within cultivated fields in the Solomeo area, near Trasimeno Lake in Central Italy (Umbria) in the years 1999 to 2000. The frogs were released into their habitat after clinical examination, ventral and toe skin biopsy (for pathological examination) and phalanx removal (for species determination). All procedures were carried out under general anaesthesia.

Host species determination. Species determination was carried out using the centromeric satellite deoxyribonucleic acid (DNA) marker RrS1, to reliably distinguish between non hybrid and hybrid frogs in Southern blot and fluorescent in situ hybridization (Ragghianti et al. 1995 and Bucci et al. 2000 provided technical details).

Statistical analysis. The Pearson chi-squared test for contingency (Kirkwood 1988) was used to analyze parasitism incidence data (positive vs negative).

Pathological examinations. Frogs were examined using a stereomicroscope and photographed. Ventral and toe skin in which gross evidence of parasitism was detected by the presence of U-shaped swellings were processed for further examination using light and electron microscopy.

For light microscopy, the specimens were fixed in $4 \%$ paraformaldehyde at $4^{\circ} \mathrm{C}$, dehydrated in graded ethanols, embedded in paraffin wax, sectioned at $4 \mu \mathrm{m}$ and stained with Haematoxylin and Eosin.

For transmission electron microscopy (TEM), the samples were fixed in $2.5 \%$ glutaraldehyde, post-fixed in $1 \%$ osmium tetroxide, dehydrated in graded ethanols and embedded in Epon-Araldite. Ultrathin sections were counterstained with uranyl acetate and lead citrate and examined with a Philips 400 TEM at $60 \mathrm{kV}$.

\section{RESULTS}

U-shaped swellings (Fig. 1) were detected in frogs examined during each year of the research. Over the course of this study, the incidence of infection was significantly higher in the parental species compared to the hybrid form $\left(1^{2}=11.61, \mathrm{p}<0.001\right)$ (Table 1). Parasite stages, comprising large clusters of encysted spores similar to those reported previously as Dermocystidium ranae, were recorded in all U-shaped swellings examined histologically $(n=25)$. These cysts were located in the stratum spongiosum of the dermis (Figs. 2 to 4 ). The cysts provoked a mild inflammatory (predominantly mononuclear) cell response (Fig. 3). Ultrastructural examination (Figs. 5 to 9) showed that mature cysts of Dermocystidium sp. contain numerous spores, each with multiple osmiophilic granules, a single membranebound nucleus, prominent nucleolus and a thick spore wall (Fig. 5). The cyst wall was composed of an osmiopilic shell attached to the connective tissue of the host, with a thickened inner wall comprised of an array of fibres packed closely together (Fig. 6). The spore wall was similarly complex, with a thickened outer layer of osmiophilic fibrous material, an intermediate bilayered 


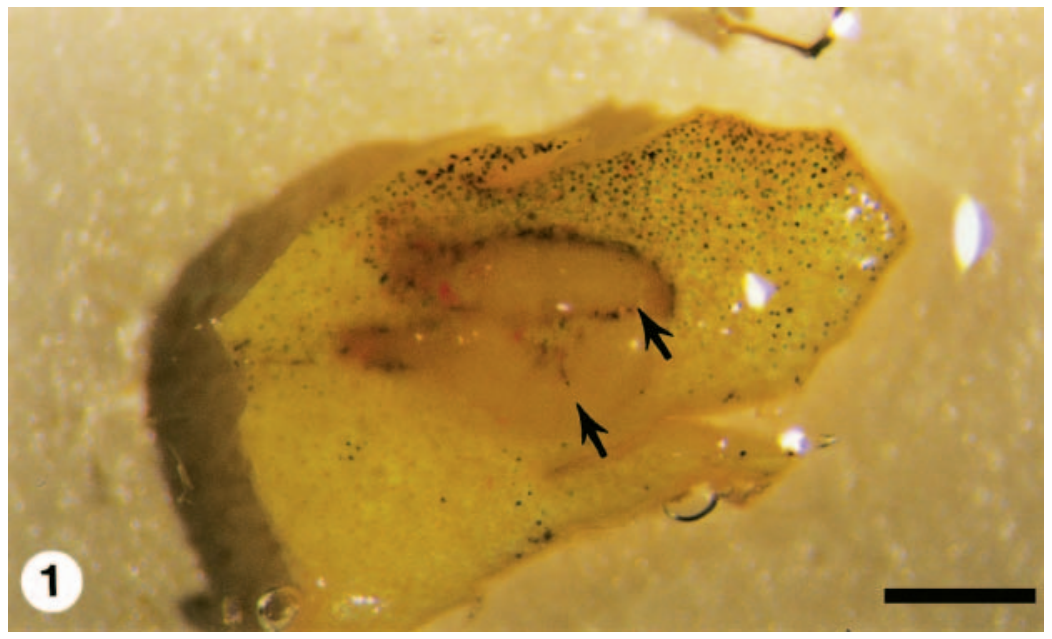

Fig. 1. Rana lessonae. Stereoscope photomicrograph of a typical U-shaped swelling on the ventral surface of an individual of the parental species $R$. lessonae. Arrows: the 2 sides of the U-shaped swelling. Scale bar $=5 \mathrm{~mm}$

(Pérez 1913), in Rana temporaria from Switzerland (Guyénot \& Naville 1922), in $R$. esculenta from France (Remy 1931), and in R. temporaria in Czechoslovakia (Brož \& Přívora 1951). The type species, D. pusula, has been reported from Triturus cristatus, $T$. marmoratus and T. palmatus (Pérez 1913, Poisson 1937). Yet other dermocystidians have been described from fish species, some of which are pathogenic (Cervinka et al. 1974, Olson et al. 1991, Landsberg \& Paperna 1992, Wildgoose 1995).

The parasite reported in the present paper is identical grossly, histopathologically and developmentally to Dermocystidium ranae, reported from Rana temporaria by Guyénot \& Naville (1922). Brož \& Přívora (1951) also found $D$. ranae in $R$. temporaria, but reported

membrane and an inner irregular (as if furrowed) layer adjacent to the spore cytoplasm (Fig. 7). In many cases, spores appeared to be subspherical and closely packed, suggesting ability to conform in shape (Fig. 8). Mitochondria were not observed in any of the spores examined. Mature spores contained multiple electrondense inclusion bodies and dense aggregations of ribosomes (Figs. 8 \& 9). Despite examination of over 500 sections of mature spores, no evidence of flagella, an apical complex, or polar tubules was found.

\section{DISCUSSION}

\section{Identity and clinical significance of the parasite}

The current study reports parasitism by a Dermocystidium sp. in a population of parental and hybrid green frogs in a small area of Central Italy where, in 1999, a $50 \%$ reduction of the parental species occurred. Dermocystidium infections have been previously reported in other European anurans: in Alytes obstetricans

Table 1. Incidence of Amphibiocystidium ranae n. comb. cysts in nonhybrids and hybrids of a Rana esculenta complex population

\begin{tabular}{|lrrcc|}
\hline $\begin{array}{l}\text { Frog } \\
\text { taxon }\end{array}$ & $\begin{array}{c}\text { Year } \\
\text { collected }\end{array}$ & $\begin{array}{c}\text { No. } \\
\text { infected }\end{array}$ & $\begin{array}{c}\text { Total } \\
\text { examined }\end{array}$ & $\begin{array}{c}\text { \% inci- } \\
\text { dence }\end{array}$ \\
\hline R. lessonae & 1999 & 10 & 22 & 45.5 \\
R. esculenta & 1999 & 3 & 21 & 14.3 \\
R. lessonae & 2000 & 11 & 21 & 52.4 \\
R. esculenta & 2000 & 5 & 29 & 17.2 \\
\hline
\end{tabular}

spores with single-inclusion bodies, rather than the multiple granules reported from spores in the current paper. However, this is probably not a relevant character, since drawings by Guyénot \& Naville (1922) show that both single and multiple bodies occur and Brož \& Přívora (1951) supplied no photomicrographs or drawings to support their findings.

The pathogenic potential of Dermocystidium ranae remains uncertain. Brož \& Přívora (1951) reported $5 \%$ incidence of $D$. ranae cysts in Rana temporaria from Czechoslovakia, supporting previous suggestions that Dermocystidium spp. are relatively benign parasites of amphibians (Guyénot \& Naville 1922). Although the incidence of parasitism found in the current study is higher than that reported by Brož \& Přívora (1951), we found no evidence that infection causes mortality or morbidity in green frogs. There was a significantly higher incidence of parasitism in $R$. lessonae (which declined by $>50 \%$ ) than in $R$. esculenta (stable population), but such data are insufficient for deducing the impact of infectious diseases on populations (McCallum \& Dobson 1995). In the absence of transmission experiments and systemic post mortem examinations of wild-collected carcasses, the ecological significance of Dermocystidium sp. to amphibians remains unknown. The cause of the recent $50 \%$ reduction of the parental form has yet to be elucidated.

\section{Taxonomic revision}

The original description of the genus Dermocystis (later renamed Dermocystidium) was published almost 100 yr ago (Pérez 1907). Since then, many of the diagnostic characters have been invalidated (see Table 2 

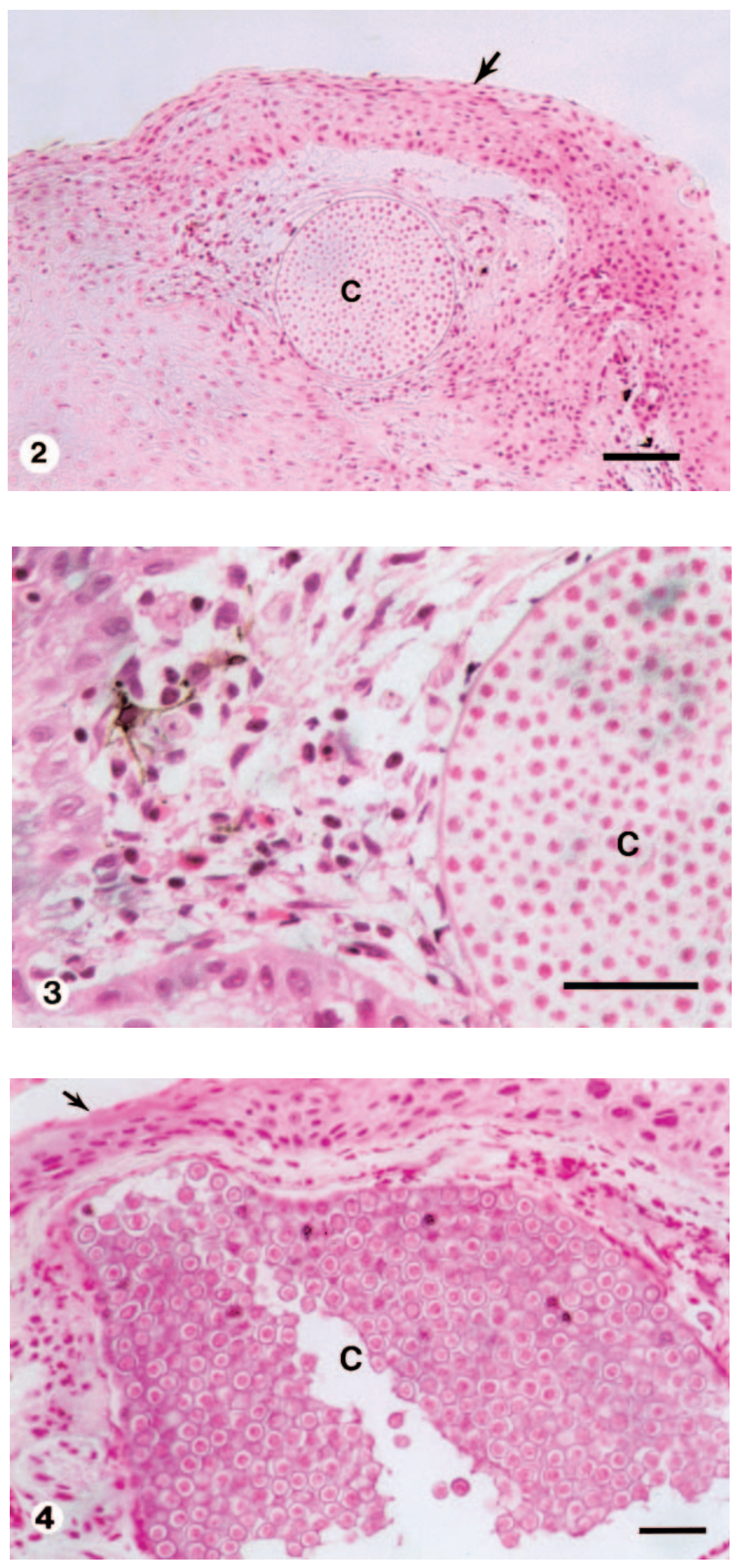

and discussion below) and techniques such as TEM and DNA sequencing have uncovered new taxonomically useful characters. Table 2 lists key taxonomic criteria for all amphibian and 3 fish Dermocystidium spp., and 2 other closely related genera from amphibians. These characters are not adequate to distinguish between species, and it is clear that the validity of all 3 genera in amphibians and their relationship to fish dermocystidians is in question. We propose the following taxonomic changes to address these problems:

(1) Synonymy of Dermosporidium multigranulare and Dermocystidium ranae. Brož \& Kulda (1954) separated $D$. multigranulare from $D$. ranae by the spherical cyst shape, presence of septa around single spores in the former and differences in spore size. The first character is invalidated by the authors' description of $D$. multigranulare cysts comprising 'an elongated cylinder bent in the form of a U'. The second character is invalidated because Guyénot \& Naville (1922) also reported septa around single spores of $D$. ranae. The authors use spore size as a character but do not state whether measurements were made of live or fixed spores, or on spores within fixed and processed tissue. They also do not give ranges. Wide variations in spore size for other parasites in these genera suggest that overlap is very likely between $D$. multigranulare and D. ranae.

Figs. 2 to 4. Rana esculenta. Photomicrographs of H\&E-stained paraffin sections of the hind feet of the hybrid form $R$. esculenta from ponds and streams near Trasimeno Lake, Italy. Fig. 2. A parasite cyst (c) within the stratum spongiosum of the dermis containing numerous spores. Note the almost complete absence of an inflammatory, or other tissue, reaction. Arrow: superficial epidermis. Scale bar $=100 \mu \mathrm{m}$. Fig. 3. Higher magnification of the parasite cyst (c) in Fig. 2. A slight infiltrate of mixed inflammatory cells is visible to the left of the cyst. Scale bar $=50 \mu \mathrm{m}$. Fig. 4. A parasite cyst (c), similar to that shown in Fig. 2, but one in which the cyst wall is less obvious and with protrusion of the cyst towards the skin surface (arrow). Scale bar $=50 \mu \mathrm{m}$ 

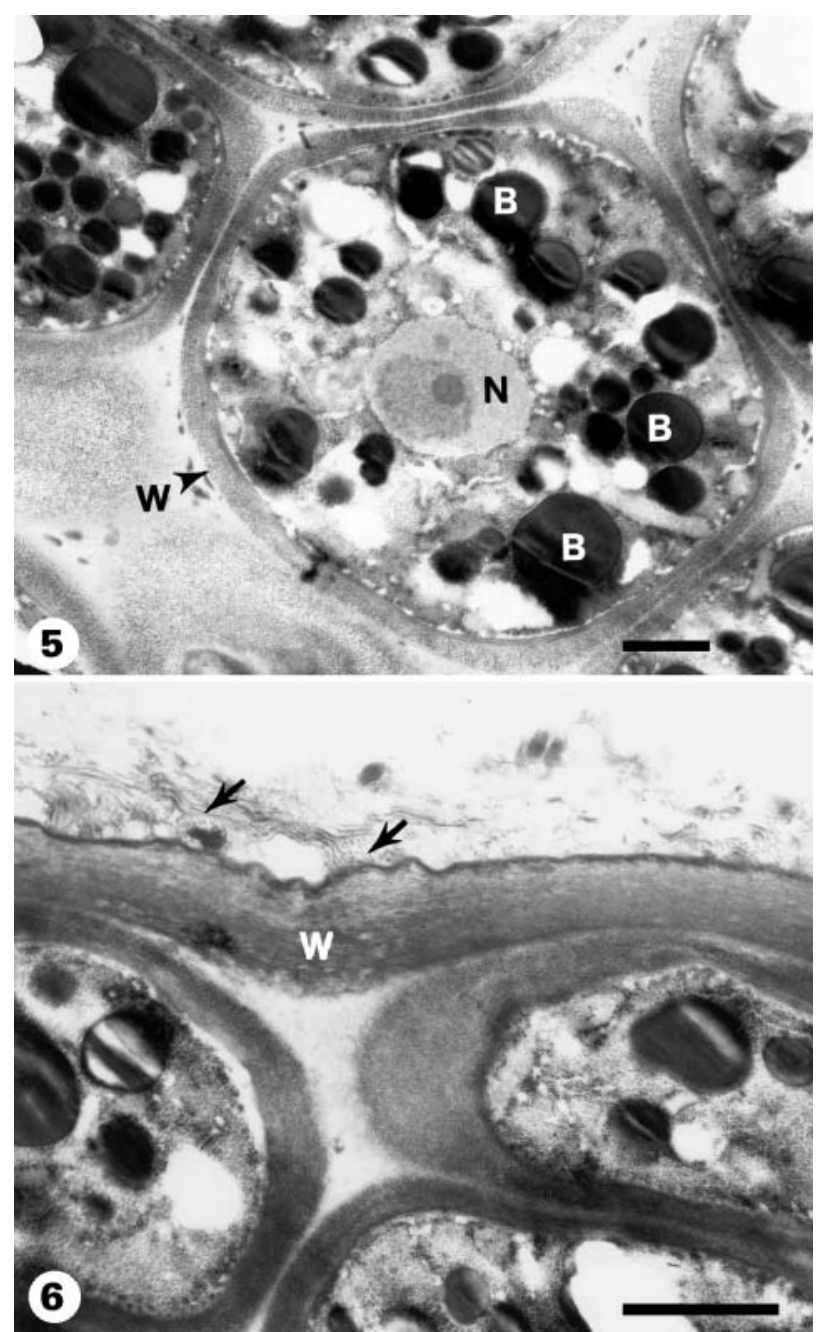

Figs. 5 to 9. Amphibiocystidium ranae infecting Rana lessonae. Transmission electron micrographs of plasticembedded tissue taken from $A$. ranae-infected green frogs (parental species) collected in ponds and streams near Trasimeno Lake, Italy. Fig. 5. Mature spores of A. ranae. Multiple inclusion bodies (B), a single nucleus (N) and the spore wall $(\mathrm{W})$ are visible. Scale bar $=2 \mu \mathrm{m}$. Fig. 6 . Cyst wall (W). Note the multiple layered structure and attachment to host collagen (arrows). Scale bar $=2 \mu \mathrm{m}$. Fig. 7. Walls of 2 adjacent spores. The wall comprises 3 layers, a thick outer fibrous layer (F), an intermediate membrane bilayer (I) and an inner furrowed host cell membrane (arrow). Scale bar = $0.5 \mu \mathrm{m}$. Fig. 8. A mature spore, demonstrating the irregular outline due to close packing of spores within the cysts. Scale bar $=1 \mu \mathrm{m}$. Fig. 9. A mature spore. Note the presence of densely packed ribosomes $(\mathrm{Rb})$. Scale bar $=1 \mu \mathrm{m}$

(2) Synonymy of the genera Dermomycoides, Dermosporidium and amphibian Dermocystidium parasites and designation of Amphibiocystidium n. gen. Previous workers (Guyénot \& Naville 1922, Brož \&
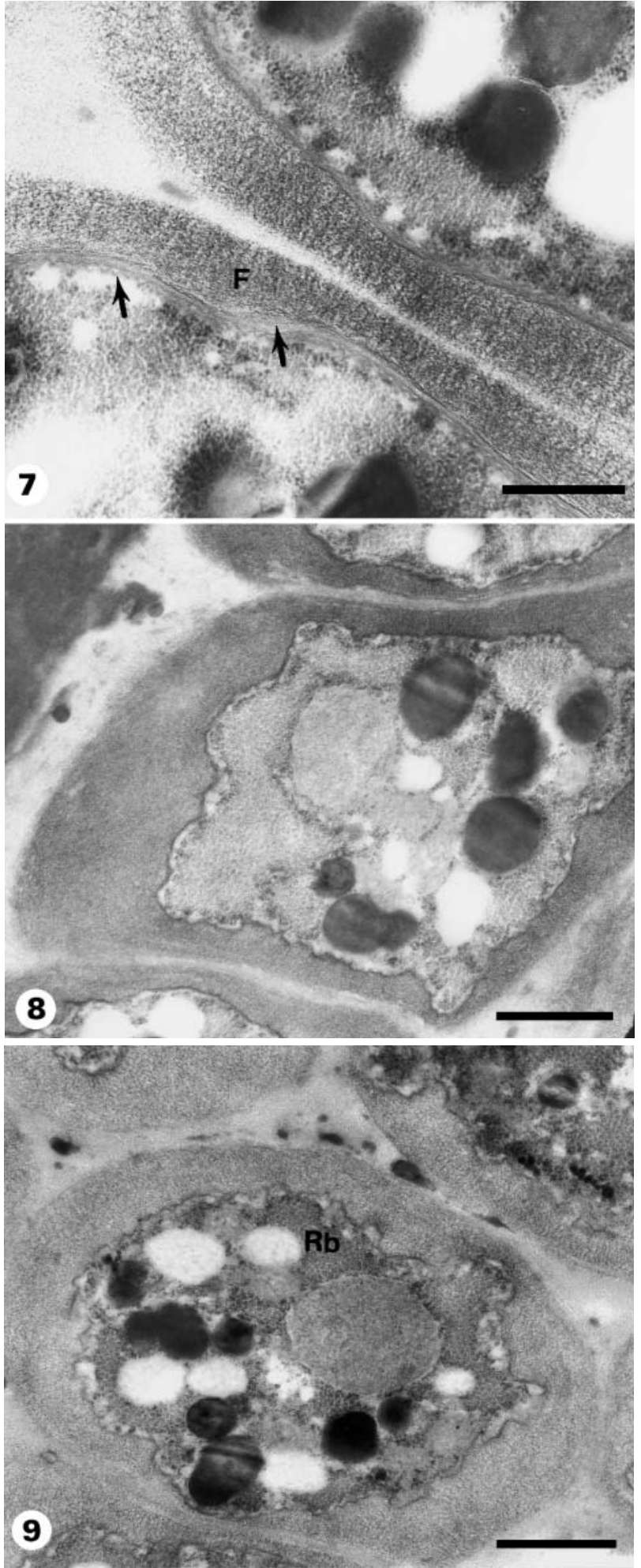

Přívora 1951, Brož \& Kulda 1954) distinguished cysts of Dermocystidium spp. and Dermosporidium spp. primarily by the U-shaped cysts and presence of septa around single spores in the former. Table 2 reveals 


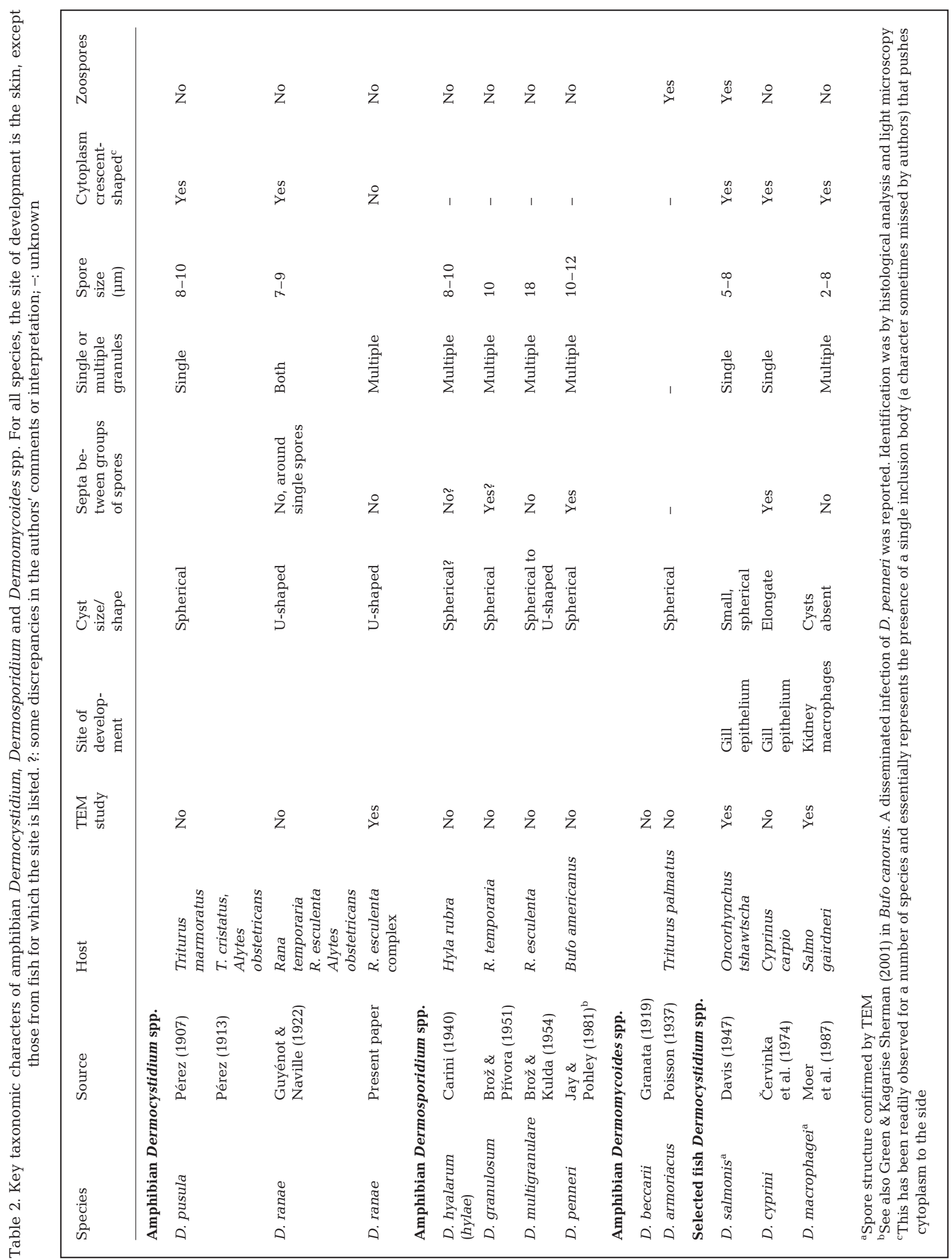


inconsistencies and incomplete data for both criteria in both genera. Other criteria used are also inadequate: although the depth of development varies slightly, cysts of all species develop in the connective tissue of the superficial dermis just below the basement membrane of the epidermis; slight variations exist in the pathological changes around cysts, but these may partly be due to observations of cysts at different stages of development. Neither criteria are widely used as generic taxonomic characters in other parasitic groups, and the latter is essentially a response to infection. In his description of the third genus in this group, Dermomycoides, Granata (1919) published 'preliminary results' of his observations, pending 'research on living material and possibly attempting some cultures and artificial infections' - work that was unfortunately not completed. Granata (1919) used presence of septa around single spores, site of development and histopathological observation of the host reaction to cyst development as distinguishing characters. For the reasons outlined earlier, these are insufficient for generic status. Furthermore, cysts of Dermomycoides spp., Dermosporidium spp. and Dermocystidium spp. are macroscopic, spherical in transverse section, located just below the epidermis and therefore indistinguishable histopathologically (Granata 1919, Poisson 1937). The only exception to this is the recent report of a disseminated Dermosporidium penneri infection in a single speciment of Bufo canorus (Green \& Kagarise Sherman 2001). Macroscopic dermal cysts consistent with $D$. penneri were reported along with the presence of cells identical to $D$. penneri spores in visceral organs. Because this is the only report of a systemic infection by a Dermomycoides spp., Dermosporidium spp. or Dermocystidium spp., we suggest that it does not have taxonomic significance, however further work (TEM, DNA sequencing) should be conducted on this specimen to further confirm the parasite's identity.

The classification of Dermomycoides armoriacus is blurred by the description of 3 types of cyst: large 'primary' cysts containing spherical spores, small 'secondary' cysts containing flagellated zoospores, and occasionally observed 'durable' cysts (Poisson 1937). In our opinion, it is possible that the 'durable' cysts are cysts that failed to mature and became encapsulated. Poisson (1937) suggested that the contents of 'secondary' cysts denote affinity to the Chytridiomycota (chytridiales). It is possible that these structures represent a stage in the life cycle of amphibian Dermosporidium, Dermocystidium or Dermomycoides that has been missed by previous workers. It is equally likely that the authors were observing a dual infection with a zoosporic fungus (possibly the first description of chytridiomycosis). We propose that these secondary cysts should not be used in generic considerations until further specimens are available. In conclusion, we propose that all 3 genera are nomina dubia when applied to amphibian host species and are synonymous.

Amphibian parasites of all 3 genera are significantly different in structure and development to fish Dermocystidium spp., therefore designating them as Dermocystidium is not appropriate. Fish dermocystidians occur in a range of tissues and their morphology varies from species that lack a cyst stage through those that form microscopic cysts to those with macroscopic cysts. Fish Dermocystidium spp. have been repeatedly recovered and characterized, and some have a zoosporic phase to their life cycle that is well established. Published information exists on the ultrastructure, DNA sequence phylogeny and life cycles of fish dermocystidians, whereas the amphibian parasites are very poorly known, with only 1 TEM report (present paper), no sequence data, no full life cycles elucidated, and transmission experiments carried out on none. Following the arguments above, we consider designation of a new genus for the current 3 amphibian genera the most logical and parsimonious option for this group of organisms. The genus Dermocystidium was described from an amphibian and therefore would normally be retained for this group of amphibian parasites. However, the Dermocystidium spp. parasitic in fish have been the subject of far more intense scientific interest over the past 50 yr than their amphibian counterparts. To avoid reclassification of the fish parasites, we believe that Dermocystidium should be retained for fish Dermocystidium spp. The International Commission for Zoological Nomenclature (ICZN) allows for such cases, under article 23.9.3, to avoid confusion or instability (International Commission on Zoological Nomenclature 1999). We have formally requested planary action from the ICZN to designate Dermocystidium salmonis Davis, 1947 (the most well-characterized Dermocystidium sp. from fish) as the type for this genus (P. Daszak \& A. A. Cunningham unpubl.). Fish Dermocystidium spp. can easily be distinguished from the amphibian parasites by their occurrence in piscine hosts, their ultrastructural differences (see below) and their life cycle details.

Characters originally used to define Dermocystis are insufficient for the purposes of designating the amphibian parasites, as are those for Dermosporidium. Using these genera to group all amphibian parasites named in Table 2 would likely lead to confusion by implying that the characters used to define these genera were valid. Herr et al. (1999) commented that Dermosporidium hyalarum (Carini 1940), often mis-named $D$. hylae, and $D$. granulosum may be synonymous with Rhinosporidium seeberi, partly because Carini (1940) originally named $D$. hyalarum as a Rhinosporidium sp. 
However, Herr et al. (1999) made this comment based on some histological similarities between the original descriptions of the amphibian parasites and data on $R$. seeberi, and their parasitism of terrestrial vertebrates. No DNA sequence data, nor detailed life history nor detailed morphological information (high-quality photomicrographs, or electron micrographs) for the amphibian species have been published that support such an assumption.

We propose that the amphibian parasites listed in Table 2 be grouped in a new genus, Amphibiocystidium n. gen. (Table 3). Type specimens (including resin-embedded blocks for electron microscopy) of Amphibiocystdium ranae n. gen. n. comb. have been deposited at the Zoological Society of London's Pathology Museum Archive, accession number H50/99. Paratypes are H49/99, H41/01 and H42/01. We therefore believe that the most parsimonious taxonomy is that Amphibiocystidium n. gen. n. comb. is a sister taxon to Dermocystidium and Rhinosporidium. The taxonomy of these groups is unlikely to remain static; however, placing Amphibiocystidium within Rhinosporidium or Dermocystidium does not represent an accurate synthesis of our current knowledge (including data within this paper).

For many groups of organisms, the taxonomic changes proposed above would be considered significant. However, it is important to note that in the almost $100 \mathrm{yr}$ since the first reports of these genera, a number

Table 3. Taxonomic designation of Amphibiocystidium n. gen.

\begin{abstract}
Amphibiocystidium n. gen.
Type species: Amphibiocystidium ranae n. comb. ${ }^{\mathrm{a}}$

Type host: Rana esculenta complex, a hybridogenetic system of green frogs including parental species $(R$. lessonae) and clonal hybrids (R. esculenta).

Type locality: Solomeo, Umbria, Central Italy

Description: Parasites infecting the dermis of amphibian hosts. Macroscopic, spherical-subspherical or U-shaped cysts containing numerous spherical-subpspherical spores 7 to $12 \mu \mathrm{m}$ in diameter. Hyphae not present, flagellated zoospores not present, polar tubes not present, apical complex not present.
\end{abstract}

Species designated to this genus (and authorities): Dermocystidium pusula Pérez, 1907

Dermocystidium ranae Guyenot \& Naville, 1922

Dermosporidium hylae Carini, 1940

Dermosporidium granulosum Brož \& Přívora, 1951

Dermosporidium multigranulare Brož \& Kulda, 1954

Dermosporidium penneri Jay \& Pohley, 1981

Dermomycoides beccarii Granata, 1919

Dermomycoides armoriacus Poisson, 1937

${ }^{a}$ Type specimens of Amphibiocystdium ranae n. gen. n. comb. have been deposited at the Zoological Society of London's Pathology Museum Archive, accession number H50/99. Paratypes are H49/99, H41/01 and H42/01 of authors have proposed synonymy between them or other genera, and a number of species have been reclassified. Furthermore, no full life cycles have been described for any of the amphibian parasites, and neither sequencing nor comparative ultrastructural studies have been performed. At best, these parasites were described from small numbers of specimens collected by different authors decades apart and during a time when systematics of the basal fungal-protistan lineages was poorly known. Some were described from preliminary results of fixed samples from a single-host specimen, or possible dual infections. Further studies (e.g. sequencing, life cycle, transmission experiments, TEM) may allow further insights into their taxonomy, but we believe our revisions represent the most efficient and useful classification at present.

\section{Phylogenetic position of Amphibiocystidium n. gen.}

The phylogenetic position of fish Dermocystidium spp. has recently been reassessed and the genus designated to the Dermocystidium-Rosette agentIchthyophonous-Psorospermium ('DRIPs') clade of aquatic parasites that infect fish, amphibians and humans (Ragan et al. 1996, Herr et al. 1999, Fredricks et al. 2000). More recent taxonomic review places fish Dermocystidium and other DRIPs within the Kingdom Protozoa, Phylum Neomonada, Class Mesomycetozoea (Mendoza et al. 2002). This class is in an interesting phylogenetic position near the animal-fungal divergence and contains genera with previously uncertain taxonomic designation. Thus, we propose that the genus Amphibiocystidium probably represents a sister clade to Dermocystidium and Rhinosporidium within the Mesomycetozoea.

The present study represents the first ultrastructural analysis of a species previously assigned to the genus Dermocystidium in amphibians and confirms their Eukaryotic nature. Despite suboptimal infiltration of cysts and the examination of only mature stages, a preliminary comparison between Amphibiocystidium ranae n. sp. and Dermocystidium species from fish hosts can be made. Firstly, no zoospores were found in the former. Olsen et al. (1991) demonstrated that flagellated zoospores of $D$. salmonis develop from mature spores with single inclusion bodies after $15 \mathrm{~d}$ incubation in fresh water at $4^{\circ} \mathrm{C}$. Developing zoospores were observed within spores only after removal from infected gills and following incubation in fresh water. If this were the case for Amphibiocystidium n. gen., we would expect to see flagella or basal bodies inside the spores, both of which were absent. Thus, although we cannot confirm that Amphibiocystidium n. gen. is not a flagellated zoosporic group of organisms until further 
work on excysted spores has been conducted, it appears unlikely. The ultrastructure of the spores described in the current study differs from that of any Dermocystidium sp. of fish described by TEM. Firstly, no fish spp. have similar multiple dense bodies. $D$. macrophagei contains multiple small granules only during early spore maturation (Moer et al. 1987), whereas Olsen et al. (1991) report only single inclusion bodies from $D$. salmonis. Dense aggregations of ribosomes are present within $A$. ranae n. comb. spores whereas spores of fish Dermocystidium spp. contain ribosomes disseminated throughout the cytoplasm. Our ultrastructural findings therefore support this genus' separate status to fish Dermocystidium.

None of the structures observed in the current study suggest that Amphibiocystidium n. gen. belongs to a Microsporidian or Apicomplexan lineage, and it is clear that there is a close relationship to fish Dermocystidium spp. Until DNA sequence analysis, or ultrastructure of the Amphibiocystidium mitochondrion is reported, we would suggest that this group is a sister genus of fish Dermocystidium and likely another member of the DRIPs clade (Ragan et al. 1996).

\section{CONCLUSIONS}

Our paper reports the presence of an enigmatic parasite from an important amphibian hybridogenetic system. Future work may allow a more accurate assessment of the pathogenicity of this and related infections in the parental species and hybrid forms, and further our understanding of the ecology of parasites within this system. Our analysis of similar parasite species described from amphibians and fish support our conclusion that Dermosporidium multigranulare Brož \& Kulda, 1954 is synonymous with Dermocystidium ranae Guyénot \& Naville, 1922 and, due to lack of sufficient differences between genera and significant dissimilarities with fish Dermocystidium spp., the 3 amphibian genera are synonymous and should be designated to a new genus, Amphibiocystidium n. gen. Amphibiocystidium n. gen. holds an interesting phylogenetic position close to the fungal-animal divergence and to a number of important pathogens such as fish Dermocystidium species, Batrachochytrium dendrobatidis, the causative agent of amphibian chytridiomycosis (Longcore et al. 1999) and Rhinosporidium sebeeri, the agent of a granulomatous disease of humans and animals (Herr et al. 1999, Fredricks at al. 2000). We believe that future work on the taxonomy, phylogeny, life cycles and pathology of these parasites will therefore be of significance to the wider field of infectious disease biology.
Acknowledgements. We are grateful to Professor S. J. Ball (Kingston University) for useful discussions on taxonomy, to Mr. Carlo Corvaja for the translation of Italian papers, and to H. Hotz (University of Zurich), G.-D. Guex (University of Zurich) and G. Mancino (University of Pisa) for their helpful comments on the green frog complex. This work was supported by core funding for the Consortium for Conservation Medicine from the V. Kann Rasmussen Foundation, by grants from University of Perugia, Italy, and by a National Science Foundation IRCEB grant (IBN \#9977063).

\section{LITERATURE CITED}

Berger L (1967) Embryonal and larval development of F1 generation of green frogs different combinations. Acta Zool Cracov 12:123-160

Berger L, Speare R, Daszak P, Green DE and 10 others (1998) Chytridiomycosis causes amphibian mortality associated with population declines in the rain forests of Australia and Central America. Proc Natl Acad Sci USA 95: 9031-9036

Blaustein AR, Wake DB (1990) Declining amphibian populations a global phenomenon. Trends Ecol Evol 5:203-204

Brož O, Kulda J (1954) Dermosporidium multigranulare n.sp parasit z kuze Rana esculenta. Acta Soc Zool Bohem 18: 91-97

Brož O, Přívora M (1951) Two skin parasites of Rana temporaria: Dermocystidium ranae Guyènot Naville and Dermosporidium granulosum n.sp. Parasitology 42:65-69

Bucci S, Ragghianti M, Guerrini F, Cerrini V, Morosi A, Mossone M, Pascolini R, Mancino G (2000) Negative environmental factors and biodiversity: the case of the hybridogenetic green frog system from Lake Trasimeno. Ital J Zool 67:365-370

Carini A (1940) Sobre um parasito semelhante ao 'Rhinosporidium' encontrado em quistos da pele de uma 'Hyla'. Arq Inst Biol (Sao Paulo) 11:93-98

Červinka S, Vítovec J, Lom J, Hoška J, Kubu R (1974) Dermocystidiosis - a gill disease of the carp due to Dermocystidium cyprini n.sp. J Fish Biol 6:689-699

Cunningham AA (2001) Investigations into mass mortalities of the common frog (Rana temporaria) in Britain: epidemiology and aetiology. PhD thesis, University of London

Cunningham AA, Langton TES, Bennett PM, Lewin JF, Drury SEN, Gough RE, Macgregor SK (1996) Pathological and microbiological findings from incidents of unusual mortality of the common frog (Rana temporaria). Phil Trans R Soc Lond B 351:1529-1557

Daszak P, Berger L, Cunningham AA, Hyatt AD, Green E, Speare R (1999) Emerging infectious and amphibian population declines. Emerg Infect Dis 5:735-748

Daszak P, Cunningham AA, Hyatt AD (2000) Emerging infectious diseases of wildlife-threats to biodiversity and human health. Science 287:443-449

Davis HS (1947) Studies of the protozoan parasites of freshwater fishes. Fish Bull Fish Wildl Serv US 41:1-29

Fioramonti E, Semlitsch RD, Reyer HU, Fent K (1997) Effects of triphenyltin and $\mathrm{pH}$ on the growth and development of Rana lessonae and Rana esculenta tadpoles. Environ Toxicol Chem 16:1940-1947

Fredricks DN, Jolley JA, Lepp PW, Kosek JC, Relman DA (2000) Rhinosporidium seeberi: a human pathogen from a novel group of aquatic protistan parasites. Emerg Infect Dis 6:273-282.

Graf JD, Polls Pelaz M (1989) Evolutionary genetics of the Rana esculenta complex In: Dawley RM, Bogart JP (eds) 
Evolution and ecology of unisexual vertebrates. New York State Museum Bulletin 466, Albany, p 289-302

Granata L (1919) Dermomycoides beccarii n.g n.sp nuovo enigmatico parassita di Molge vulgaris L. Monit Zool Ital 20:153-160

Green DE, Kagarise Sherman C (2001) Diagnostic histological findings in Yosemite toads (Bufo canorus) from a die-off in the 1970's. J Herpetol 353:92-103

Günther R (1973) Über die verwandtschaftlichen Beziehungen zwischen den europäischen Grünfröschen und dem Bastardcharakter von Rana esculenta L (Anura). Zool Anz 190:250-285

Günther R, Plötner J (1994) Morphometric enzymological and bioacoustic studies in Italian water frogs (Amphibia Ranidae). Zool Pol 39:387-415

Guyénot E, Naville A (1922) Un nouveau protiste du genre Dermocystidium parasite de la Grenouille Dermocystidium ranae nov. spec. Rev Suisse Zool 29:133-145

Halliday T (2001) The wider implication of amphibian population declines. Oryx 35:181-182

Herr RA, Ajello L, Taylor JW, Arseculeratne SN, Mendoza L (1999) Phylogenetic analysis of Rhinosporidium seeberi's 18S Small-Subunit Ribosomal DNA groups this pathogen among members of the protoctistan mesomycetozoa clade. J Clin Microbiol 37:2750-2754

Hotz H, Semlitsch RD, Gutman E, Geux GD, Beerli P (1999) Spontaneous heterosis in larval life-history traits of hemiclonal frog hybrids. Proc Natl Acad Sci USA 96:2171-2176

Houlahan JE, Findlay CS, Benedikt RS, Meyer AH, Kuzmin SL (2000) Quantitative evidence for global amphibian population declines. Nature 404:752-755

International Commission on Zoological Nomenclature (1999) International code on zoological nomenclature. The International Trust for Zoological Nomenclature, London

Jay JM, Pohley WJ (1981) Dermosporidium penneri sp n from the skin of the American toad Bufo americanus (Amphibia: Bufonidae). J Parasitol 67:108-110

Kiesecker JM, Blaustein AR, Belden LK (2001) Complex causes of amphibian population declines. Nature 410:681-684

Kirkwood BR (1988) Essentials of medical statistics. Blackwell Scientific Publications, Oxford

Landsberg JH, Paperna I (1992) Systemic granuloma in goldfish caused by a Dermocystidium-like aetiological agent. Dis Aquat Org 13:75-78

Longcore JE, Pessier AP, Nichols DK (1999) Batrachochytrium dendrobatidis gen. et sp. nov. a chytrid pathogenic to amphibians. Mycologia 91:219-227

McCallum H, Dobson A (1995) Detecting disease and parasite threats to endangered species and ecosystems. Trends Ecol Evol 10:190-194

Mendoza L, Taylor JW, Libero A (2002) The class Mezomycetozoea: a heterogeneous group of microorganisms at the

Editorial responsibility: Peernel Zwart,

Utrecht, The Netherlands animal-fungal boundary. Annu Rev Microbiol 56:315-344

Moer A, Manier JF, Bouix G (1987) Étude ultrastructurale de Dermocystidium macrophagi n sp parasite intracellulaire de Salmo gairdneri Richardson 1836. Ann Sci Nat Zool Biol Anim 8:143-151

Olson RE, Dungan CF, Holt RA (1991) Water-borne transmission of Dermocystidium salmonis in the laboratory. Dis Aquat Org 12:41-48

Pérez C (1907) Dermocystis pusula organisme nouveau parasite de la peau des tritons. C R Soc Biol 63:445-447

Pérez C (1913) Dermocystidium pusula parasite de la peau des tritons. Arch Zool Exp Gen 52:343-357

Poisson R (1937) Sur une nouvelle espèce du genre Dermomycoides Granata 1919: Dermomycoides armoriacus Poisson 1936 parasite cutané de Triturus palmatus (Schneider): genèse et structure de la zoospore. Bull Biol (Woods Hole) 71:91-116

Ragan MA, Goggin CL, Cawthorn RJ, Cerenius L and 5 others (1996) A novel clade of protistan parasites near the animal-fungal divergence. Proc Natl Acad Sci USA 93: 11907-11912

Ragghianti M, Guerrini F, Bucci S, Mancino G, Hotz H, Uzzel T, Guex GD (1995) Molecular characterization of a centromeric satellite DNA in the hemiclonal hybrid frogs Rana esculenta and its parental species. Chromosome Res 3:497-506

Remy P (1931) Presence de Dermocystidium ranae (Guyenot et Naville) chez une Rana esculenta L. de Lorraine. Ann Parasitol 9:1-3

Schultz RJ (1969) Hybridization, unisexuality and polyploidy in the teleost Poeciliopsis (Poeciliidae) and other vertebrates. Am Nat 103:605-619

Semlitsch RD, Reyer HU (1992) Performance of tadpoles from the hybridogenic Rana esculenta complex: interactions with pond drying and interspecific competition. Evolution 46:665-676

Tunner HG, Heppich-Tunner S (1991) Genome exclusion and 2 strategies of chromosome duplication in oogenesis of a hybrid frog. Naturwissenschaften 78:32-34

Tunner HG, Nopp H (1979) Heterosis in the common European waterfrog. Naturwissenschaften 66:268-269

Uzzell T (1983) An immunological survey of Italian water frogs Salentia: Ranidae). Herpetologica 39:225-234

Uzzell T, Berger L (1975) Electrophoretic phenotypes of Rana ridibunda Rana lessonae and their hybridogenetic associate Rana esculenta. Proc Acad Nat Sci Phila 127:13-24

Uzzell T, Hotz H (1979) Electrophoretic and morphological evidence for the 2 forms of green frogs (Rana esculenta complex) in peninsular Italy (Amphibia Salientia). Mitt Zool Mus Berl 55:13-27

Wildgoose WH (1995) Dermocystidium koi found in skin lesions in koi carp (Cyprinus carpio). Vet Rec 137:317-318

Submitted: March 20, 2002; Accepted: April 10, 2003

Proofs received from author(s): July 18, 2003 